\title{
Neuronal cues regulate uptake in cultured astrocytes
}

\section{J. CUMMINS*, R. A. GLOVER and O. Z. SELLINGER}

Department of Human Genetics, (R.A.G.) Department of Anatomy, and (O.Z.S.) Laboratory of Neurochemistry, Mental Health Research Institute, University of Michigan Medical Center, Ann Arbor, Mich., 48109 (U.S.A.)

(Accepted March 8th, 1979)

Astrocytes of the vertebrate central nervous system are postulated to nourish neurons ${ }^{4,10,13}$, to electrically insulate cortical neuronal columns ${ }^{15}$, to cue patterns of developmental migrations of neurons ${ }^{14}$, and to regulate the ionic environment of brain ${ }^{5}$, 17,19. Despite persistent investigation, the function or functions of this phylogenetically ubiquitous cell type remain largely hypothetical. Neurons and their attendant glia are considered to be a functional metabolic unit. For this to be the case, at least two criteria must be met: (1) some mechanism must exist for communication of relevant information about the metabolic state of one cell-type to the other; and (2) either cell-type must be able to alter its metabolism in response to cues emitted by the other. Although the spectrum of neuronally emitted cues is large, ideally, such cues should reflect some aspect of neuronal activity. In the present study we have selected extracellular $\mathrm{K}^{+}$and 3 putative neurotransmitters as neuronal cues, since it is known that the cerebral levels of both reflect neuronal activity and that each also affects glial membrane potential ${ }^{8,18}$, oxygen uptake ${ }^{1}$ and cyclic nucleotide levels ${ }^{3,9,11}$. One manner in which neurons may affect glial metabolism is by inducing alterations in the glial uptake of key metabolites, such as glucose, possibly a rate-limiting step in cerebral glycolysis ${ }^{16}$ and selected amino acids, the uptake of which by the glial cells may, in part, reflect transfer from the extracellular space of brain tissue ${ }^{7,12}$.

Recently, we developed a technique for the cultivation of a purified population of astrocytes, derived from neonatal rat forebrain ${ }^{2}$ and in the present study we investigate the effect of neuronal cues (see above) on the astrocytic uptake of the glucose analogue 2-deoxy-D-glucose (2-DOG) and of L-methionine (MET), the precursor amino acid essential for the cerebral synthesis of the universal methyl donor molecule, S-adenosylL-methionine.

Under the conditions of the experiment described in Fig. 1, the uptake of 2-DOG remained linear for at least $15 \mathrm{~min}$. To determine the effects of extracellular $\mathrm{K}^{+}$on the uptake of 2-DOG, $\mathrm{KCl}$ replaced $\mathrm{NaCl}$ on a molar basis. Plates of confluent cells were incubated with $0.25,0.50$, and $1.0 \mathrm{mM} 2-\mathrm{DOG}$ at the indicated concentrations of extra-

\footnotetext{
* Present address: Laboratory of Neurochemistry, NINCDS, NIH, Bethesda, MD 20014, U.S.A.
} 


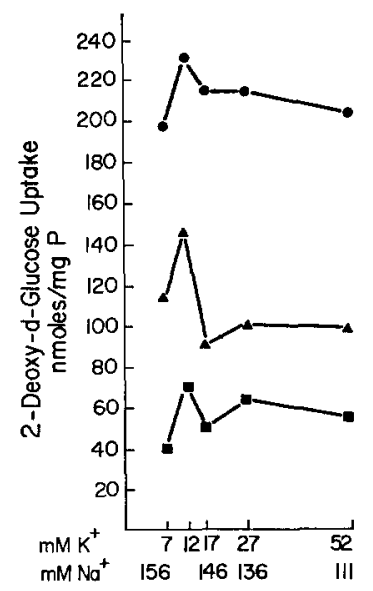

Fig. 1. The effect of extracellular $\mathrm{K}^{+}$on the uptake of 2-DOG. Cerebra from 3-5-day-old male rats were dissected under sterile conditions minced with a razor blade and trypsinized in $0.25 \%(w / v)$ trypsin in Hank's or Earle's balanced salt solution. Fragments were pelleted at $1000 \times g$, the pellet resuspended in $10 \mathrm{ml}$ of tissue culture medium containing $10 \%$ fetal bovine serum, and aliquoted into Falcon flasks or tissue culture dishes. Cells are confluent in 12-14 days ${ }^{2}$. All experiments were done on cells re-fed within the preceding $48 \mathrm{~h}$. For each experiment, dishes were washed free of media with $15 \mathrm{ml}$ of isotonic saline at $37^{\circ} \mathrm{C}$, and incubated in the presence of 2-DOG containing $1.0 \mu \mathrm{Ci}$ of [G- $\left.{ }^{-} \mathrm{H}\right] 2-\mathrm{DOG}(10 \mathrm{Ci} /$ mmol, New England Nuclear, Boston, Mass.) in a buffer containing $5.3 \mathrm{mM} \mathrm{KCl}, 150 \mathrm{mM} \mathrm{NaCl}, 1.0$ $\mathrm{mM} \mathrm{CaCl}, 0.6 \mathrm{mM} \mathrm{MgCl}_{2}, 1.6 \mathrm{mM} \mathrm{KH}_{2} \mathrm{PO}_{4}$ and $4.3 \mathrm{mM} \mathrm{Na}_{2} \mathrm{HPO}_{4}$, in a $95 \% / 5 \%$ air $/ \mathrm{CO}_{2}$ incubator for $15 \mathrm{~min}$. Uptake was terminated by pouring off the medium, and rapidly washing the dishes with icecold saline. The cells were then digested with $2.0 \mathrm{ml}$ of $0.4 \mathrm{M} \mathrm{NaOH}$ for the measurement of intracellular 2-DOG ${ }^{6}$. Aliquots were neutralized and counted in duplicate. 2-DOG concentration (in $\mathrm{mM}$ ): 0.25 , squares; 0.50 , triangles; and 1.0 , circles.

\section{TABLE I}

\section{Uptake of 2-DOG or MET by primary cultures of astrocytes}

Dishes of confluent cells were incubated with $500 \mu \mathrm{M}$ 2-DOG (as in Fig. 1) or with $500 \mathrm{nM}$ MET (as in Fig. 2) in $2.0 \mathrm{ml}$ of buffer (described above), with a final concentration of $\mathrm{K}^{+}$of $6.9 \mathrm{mM}$. Agents were added to the final concentration indicated. Controls contained no added agents. Uptake values represent the mean \pm S.E.M. of duplicate determinations on 3-5 dishes. Asterisk indicates a significant difference $(P<0.05)$ from control values by the Student's $t$-test. ND, not done.

\begin{tabular}{|c|c|c|c|c|}
\hline Agent & $\begin{array}{l}\text { 2-DOG uptake } \\
(\mathrm{nmol} / \mathrm{mg} \text { protein } / \\
15 \mathrm{~min})\end{array}$ & $\%$ Control & $\begin{array}{l}\text { MET uptake } \\
\text { (pmol/mg protein/ } \\
2.5 \mathrm{~min})\end{array}$ & $\%$ Control \\
\hline Control & $152 \pm 9$ & 100 & $94 \pm 3$ & 100 \\
\hline $\mathrm{Ca}^{2+}$-free & $86 \pm 9 *$ & 57 & ND & \\
\hline 5-HT $(1 \mu \mathrm{M})$ & $111 \pm 6^{*}$ & 73 & ND & \\
\hline $\mathrm{dbcAMP}(1 \mu \mathrm{M})$ & $155 \pm 4$ & 102 & $55 \pm 5$ & 59 \\
\hline GABA $(1 \mu \mathrm{M})$ & $134 \pm 7$ & 88 & $99 \pm 5$ & 105 \\
\hline Ouabain $(10 \mu \mathrm{M})$ & $174 \pm 16$ & 114 & $74 \pm 4$ & 80 \\
\hline \multicolumn{5}{|l|}{ NE } \\
\hline $50 \mathrm{nM}$ & ND & & $180 \pm 18^{*}$ & 191 \\
\hline $500 \mathrm{nM}$ & ND & & $194 \pm 19^{*}$ & 206 \\
\hline $1 \mu \mathrm{M}$ & $130 \pm 5^{*}$ & 86 & ND & \\
\hline $5 \mu \mathrm{M}$ & ND & & $200 \pm 20^{*}$ & 213 \\
\hline $50 \mu \mathrm{M}$ & ND & & $185 \pm 18^{*}$ & 197 \\
\hline
\end{tabular}




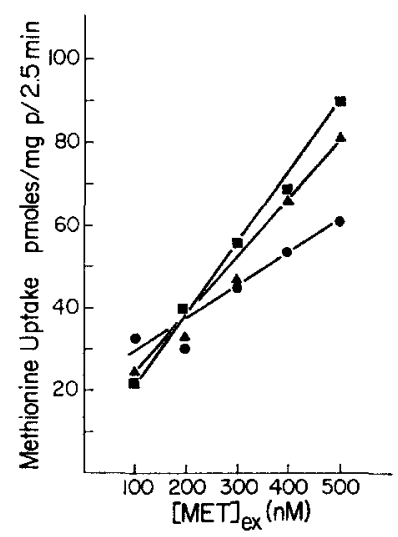

Fig. 2. $\mathrm{K}^{+}$-dependence of $\mathrm{L}$-methionine uptake. MET, as indicated, was incubated in a buffer containing $\left[\mathrm{U}-{ }^{14} \mathrm{C}\right] \mathrm{L}-\mathrm{methionine}$ (spec. act. $213 \mathrm{mCi} / \mathrm{mmol}$, New England Nuclear, Boston, Mass.); $6.9 \mathrm{mM} \mathrm{K}{ }^{+}$, squares; $11.9 \mathrm{mM} \mathrm{K}+$, circles; and $16.9 \mathrm{mM} \mathrm{K}+$, triangles. Buffer as described above. Dishes were incubated for $2.5 \mathrm{~min}$, washed as above, and the cells were disrupted by the addition of $0.2 \mathrm{~N}$ perchloric acid. Each point represents duplicate determinations on 3-5 dishes.

cellular $\mathrm{K}^{+}$. Elevation of extracellular $\mathrm{K}^{+}$to $11.9 \mathrm{mM}$ increased the uptake of 2-DOG over the uptake at $6.9 \mathrm{mM} \mathrm{K}^{+}$. Further elevations in $\mathrm{K}^{+}$caused no further increase in 2-DOG uptake.

Norepinephrine (NE), serotonin (5-HT), gamma-aminobutyric acid (GABA), ouabain and N-6, O-2'-dibutyryl-3',5'-cyclic AMP (dbcAMP) were tested to determine their effect on 2-DOG uptake in a medium containing $6.9 \mathrm{mM} \mathrm{K}^{+}$. The 3 putative neurotransmitters reduced 2-DOG uptake, NE and 5-HT significantly, while ouabain and dbcAMP had no effect. Omission of $\mathrm{Ca}^{2+}$ from the incubation medium caused a highly significant decrease of 2-DOG uptake, indicating that uptake may be a $\mathrm{Ca}^{2+}$ requiring process (Table I).

The uptake of MET was found to be linear for $2.5 \mathrm{~min}$, for up to $2.4 \mu \mathrm{M}$ (data not shown). Fig. 2 shows MET uptake in the $100-500 \mathrm{nM}$ range, and at 3 concentrations of extracellular $\mathrm{K}^{+}$. Fig. 2 also shows that at the higher concentrations of MET, elevation of extracellular $\mathrm{K}^{+}$from $6.9 \mathrm{mM}$ to $11.9 \mathrm{mM}$ decreased MET uptake significantly.

To test the effect of NE on MET uptake, dishes containing buffer with $6.9 \mathrm{mM}$ $\mathrm{K}^{+}$and $500 \mathrm{nM}$ MET were incubated at several concentrations of NE. NE at concentrations as low as $50 \mathrm{nM}$ stimulated the uptake of MET significantly.

The present study shows that the uptake of 2-DOG and MET into cultivated astrocytes is reciprocally modulated by extracellular $\mathrm{K}^{+}$and putative neurotransmitters. Whether the effects of $\mathrm{K}^{+}$and $\mathrm{NE}$ are the result of direct interaction with the relevant carrier system is not clear at this time. It is of particular interest that the extracellular concentrations of $\mathrm{K}^{+}$which elicited alterations in astrocytic uptake correspond closely to the physiological upper limit of extracellular $\mathrm{K}^{+}$in stimulated cortex ${ }^{8,18}$. Moreover, our results also suggest the possibility of the regulation of glial uptake in vivo by elevations in extracellular $\mathrm{K}^{+}$and neurotransmitter levels. Neurons may thus alter the phy- 
siological responses and/or the metabolism of astrocytes by modulating the uptake of glucose and amino acids.

The authors wish to thank Mr. Richard Fritzler for drafting the figures.

The support of the National Institute of Neurological and Communicative Disorders and Stroke, U.S.P.H.S. (OZS) is gratefully acknowledged.

1 Blomstrand, C. and Hamburger, A., Protein turnover in cell enriched fractions from rabbit brain, J. Neurochem., 16 (1969) 1401-1407.

2 Cummins, C. and Glover, R. A., Propagation and histological characterization of a homotypic population of astrocytes derived from neonatal rat brain, J. Anat. (Lond.), 125 (1978) 117-125.

3 Gilman, A. G. and Nirenberg, M., Effects of catecholamines on the adenosine $3^{\prime}, 5^{\prime}$-cyclic monophosphate concentrations of a clonal line of satellite cells of neurons, Proc. nat. Acad. Sci. (Wash.), 68 (1971) 2165-2168.

4 Golgi, C., Le reseau nerveaux diffus des centres du systeme nerveaus; ses attributs physiologiques, methods suivie dans les recherches histologiques. Arch. ital. Biol., 15 (1891) 434-463.

5 Hertz, L., Localization of the potassium and sodium effects on respiration in brain, J. Neurochem., 13 (1966) 1373-1387.

6 Kletzien, R. and Purdue, J., Sugar transport in chick embryo fibroblasts., J. biol. Chem., 249 (1974) 3366-3374.

7 Lajtha, A. and Sershen, $\mathrm{H}$., Inhibition of amino acid uptake by the absence of $\mathrm{Na}^{+}$in slices of brain, J. Neurochem., 24 (1975) 667-672.

8 Lothman, E., LaManna, J., Cordingly, G., Rosenthal, M. and Somjen, G., Responses of electrical potential, potassium levels and oxidative metabolic activity in the cerebral neocortex of the cat, Brain Research, 88 (1975) 15-24.

9 McMorris, F. A., Norepinephrine induces glial-specific enzyme activity in cultured glioma cells, Proc. nat. Acad. Sci. (Wash.), 74 (1977) 4501-4504.

10 Nageotte, G., Phenomes de secretion dans le protoplasma des cellules neurogliques de la substance grise, C.R. Soc. Biol. (Paris), 68 (1910) 1068-1069.

11 Newburg, R. and Rosenberg, R. N., Effect of norepinephrine on glucose metabolism in glioma and neuroblastoma cells in culture, Proc. nat. Acad. Sci. (Wash.), 69 (1972) 1677-1680.

12 Pardridge, W. and Oldendorf, W., Kinetics of blood-brain barrier transport of hexoses, Biochim. biophys. Acta (Amst.), 382 (1975) 377-392.

13 Penfield, W., Neuroglia, normal and pathological. In W. Penfield (Ed.), Cytology and Cellular Pathology of the Nervous System, Vol. II, Hoeber, New York, pp. 421-479.

14 Rakic, P. and Sidman, R., Organization of the cerebellar cortex secondary to deficit of granule cells in weaver mutant mice, J. comp. Neurol., 152 (1973) 133-162.

15 Ramon y Cajal, S., Histologie du System Nerveaux de l'Homme et des Vertebres, Malonie, Paris, 1909.

16 Rolleston, R. and Newsholme, E. A., The control of glycolysis in cerebral cortex slices, Biochem. J., 104 (1967) 524-533.

17 Somjen, G., Electrophysiology of neuroglia. Ann. Rev. Physiol., 37 (1975) 163-190.

18 Somjen, G., Rosenthal, M. and Lothman, E., Potassium, neuroglia, and oxidative metabolism in central grey matter, Fed. Proc., 35 (1976) 1266-1271.

19 Trachtenberg, M. and Pollen, D. Neuroglia, biophysical properties and physiological function, Science, 167 (1970) 1248-1251. 